\title{
Japanese Measures against Marine Pollution under UNCLOS and the IMO Treaties
}

Jun Tsuruta*

The purpose of this paper is to clarify the present state and problems of Japanese measures against the protection and preservation of the marine environment from the perspective of international law and Japanese domestic laws and regulations. The analysis is divided into three sections. Firstly, the relationship between Part XII of UNCLOS and the IMO marine environmental treaties will be addressed in brief. Secondly, Japanese implementation of the IMO treaties will be addressed in the context of the regulations regarding both dumping waste into the sea from vessels and marine pollution from vessels. Finally, this paper will clarify the problems regarding the Japanese implementation of marine environmental treaties.

\section{Keywords}

Marine Environment, UNCLOS, IMO, Japan Coast Guard, London Protocol

\section{The Relationship between UNCLOS and the IMO Marine Environmental Treaties}

Part XII of the United Nations Convention on the Law of the Sea ("UNCLOS")1 stipulates the adoption and enforcement of domestic laws and regulations for the prevention, reduction and control of pollution of the marine environment, such as pollution from land-based sources, pollution from seabed activities, pollution from

* Associate Professor of International Law at the Japan Coast Guard Academy. LL.B.(Sophia), LL.M.(Tokyo). The author may be contacted at: tsuruta@jcga.ac.jp/Address: The Japan Coast Guard Academy, 5-1 Wakaba-cho, Kure city, Hiroshima 737-8512 JAPAN.

1 UN Doc.A/CONF.62/122. UNCLOS came into force in 1994 and was ratified by Japan in 1996. 
dumping, pollution from vessels and pollution from or through the atmosphere etc. ${ }^{2}$ However, these articles do not set any absolute standards to prevent marine pollution, but instead adopt an form of international minimum harmonization standard based on an obligation of result. ${ }^{3}$ Absolute standards to prevent marine pollution can be found in detailed treaties related to the marine environment to be adopted by the International Maritime Organization ("IMO").

One of he contented issues regarding the enforcement of laws and regulations against foreign vessels is the interpretation of the "laws and regulations adopted in accordance with this Convention" and the "applicable international rules and standards established through the competent international organization or general diplomatic conference" as mentioned in Part XII of UNCLOS. For example, Article 210 of UNCLOS addresses pollution by dumping, and stipulates that domestic laws and regulations "shall be no less effective in preventing, reducing and controlling such pollution than the global rules and standards." It further requires States to establish goals and regional rules, standards and recommended practices and procedures "especially through competent international organizations or diplomatic conference." The IMO is generally regarded as a good example of a "competent international organization." The rules and standards adopted by the IMO are as follows: the Convention on the Prevention of Marine Pollution by Dumping of Wastes and Other Matter of 1972 ("London Convention of 1972"); 4 the 1996 Protocol on the London Convention of 1972 with regard to dumping into the sea ("London Protocol of 1996"); 5 the International Convention for the Prevention of Pollution from Ships of 1973 ("1973 MARPOL"); 6 the Protocol of 1978 relating to the International Convention for the Prevention of Pollution from Ships of 1973 ("MARPOL 73/78")7 and the Protocol of 1997 to amend the International Convention for the Prevention of Pollution from Ships, 1973, as modified by the Protocol of 1978 relating thereto ("Protocol of 1997"). 8 the Marine Environment, THE LAW of THE SEA: Progress and Prospects 188-189(David Freestone, Richard Barnes \& David M. Ong eds., 2006).

4 Entered into force in 1975; Japan acceded in 1980.

5 Entered into force in 2006; Japan acceded in 2007.

6 Not yet entered into force.

Entered into force in 1983; Japan acceded in 1983.

Entered into force in 2005; Japan acceded in 2005. 


\section{Japanese Implementation of the IMO Marine Environmental Treaties}

Japan is a Contracting Party to many marine environmental treaties adopted by the IMO, including: the London Convention of 1972; the London Protocol of 1996; the MARPOL 73/78; the Protocol of 1997; the International Convention on Oil Pollution Preparedness, Response and Co-operation of 1990 ("OPRC Convention"); 9 and the subsequent Protocol on Preparedness, Response and Co-operation to Pollution Incidents by Hazardous and Noxious Substances of 2000 ("OPRC-HNS Protocol").10

\section{A. Japanese Measures against Dumping into the Sea from Vessels}

The London Convention of 1972, its following Protocol and the London Protocol of 1996 are generally interpreted to be "global rules and standards" to prevent, reduce and control pollution of the marine environment by dumping. ${ }^{11}$ In order to regulate dumping of wastes or other matter originating from land into the sea, the London Convention of 1972 prohibited dumping of the wastes or other matter listed in Annex I ("Black List").12 The Convention further requires States to obtain "a prior special permit" regarding dumping of the wastes or other matter listed in Annex II ("Gray List"),13 and "a prior general permit" regarding dumping of any other wastes or other matter.

The London Protocol of 1996 represents a major change of the system to regulate dumping of wastes or other matter originating from land into the sea. The Protocol adopts the "precautionary approach" and the "polluter-pays principle." 14 In addition, the protocol prohibits dumping in principle, stipulating as follows: "Contracting Parties shall prohibit the dumping of any wastes or other matter with the exception of those listed in Annex I," 15 and allows the parties to consider granting a permit regarding dumping of only the wastes or other matter listed in Annex I, such as dredged material,

Entered into force in 2007; Japan acceded in 2007.

11 UNCLOS, art. 210, para. 6.

12 Annex I includes intermediate and high-level radioactive wastes, and wastes containing heavy metals such as mercury and cadmium, etc.

13 Annex II includes wastes containing a significant amount of the matters, such as arsenic, beryllium, chromium, copper, lead, nickel and vanadium, etc.

14 The London Protocol 1996, art. 3, paras. 1-2.

15 Id. at art. 4 , para. 1. 
sewage sludge, fish remnants, residue from fish-processing, vessels, platforms and manmade structures at sea, inert and inorganic geological material, and organic material of natural origin. 16

The contrast between the London Convention of 1972 and the London Protocol of 1996 is in regards to the regulations of dumping. The London Convention of 1972 (and UNCLOS) does not prohibit dumping but rather subjects it to a system of express prior approval.17 On the other hand, the so-called "negative listing approach" adopted by the London Protocol of 1996 is an example of application of the precautionary approach, and reverses the regulatory approach, from "permitted unless prohibited" to "prohibited unless permitted." 18 Under the negative listing approach, only listed substances may be permitted to be dumped, while the dumping of all other substances is prohibited. 19

In 1970, Japan adopted the Act on the Prevention of Marine Pollution and Maritime Disaster ("Marine Pollution Prevention Act"). 20 The primary purpose of the Marine Pollution Prevention Act is to "secure appropriate enforcement of international convention on the prevention of marine pollution and maritime disaster." 21 Although the Marine Pollution Prevention Act has no explicit provision on its scope of application, the Act applies to any vessel in Japanese internal waters and territorial sea,22 as well as to any Japanese vessel outside these areas. Japan amended the Marine Pollution Prevention Act in 1980 to ratify the London Convention of 1972, and then revised the Act in 2004 and 2007 in order to ratify the London Protocol of 1996. The amendment of the Act in 2004 obliged any person who will dump wastes and other matter into the sea to obtain permission for dumping from the Minister of the Environment, and to obtain a confirmation of actual dumping from the Commandant of the Japanese Coast Guard. As mentioned above, when ratifying the London Protocol of 1996, Japan amended the Marine Pollution Prevention Act in accordance with "the global rules and standards" 23 as set forth in the Protocol. These rules and standards

16 Annex I of the London Protocol 1996, Article 1, paragraph 1 stipulates as follows: "The following wastes or other matter are those that may be considered for dumping being mindful of the Objectives and General Obligations of this Protocol set out in articles 2 and 3."

17 Redgwell, supra note 3, at 187-188.

18 Id. at 188.

19 David Freestone and Salman M.A. Salman, Ocean and Freshwater Resources, in Handbook of InTERnATIONAL ENVIRonmental LaW 343-344(Daniel Bodansky, Jutta Brunnee \& Ellen Hey eds., 2007).

20 Act No. 136 of 1970.

21 Marine Pollution Prevention Act, art. 1.

22 Since the definition of "Vessel" excludes warships and ships used only in governmental non-commercial service under the IMO treaties concerning marine environment, it is generally interpreted that "Vessel" in the Marine Pollution Prevention Act also excludes such ships.

23 UNCLOS, art. 210, para. 6 . 
apply to any vessel, including foreign vessels in Japanese internal waters and territorial sea whether its flag State is a Contracting Party to the Protocol or not. From December 2006 to August 2009, the Japanese Ministry of Environment issued 60 permissions on dumping of five types of wastes and other matter, such as: (1) red mud; (2) sand and gravel on the bottom; (3) construction sludge; (4) waste acid (distilled spirit [shochu] lees); and (5) animal dung. 24

\section{B. Japanese Measures against Marine Pollution from Vessels}

The objective of the MARPOL 73/78 is to prevent, reduce and minimize marine pollution arising out of vessel operations and accidents. The MARPOL 73/78 is a combination of two treaties adopted in 1973 and 1978 respectively and updated by amendments through the years. As the 1973 MARPOL had not yet entered into force, the 1978 MARPOL Protocol absorbed the parent Convention. The combined instrument is referred to as the MARPOL 73/78, and it entered into force in 1983.

In principle, the Annexes of the MARPOL73/7825 and the Protocol of 1997 prohibit the discharge of oil, noxious liquids and other noxious wastes and gas. The MARPOL $73 / 78$ sets out the standards and methods for permissible discharges, and contains the detailed rules and standards on designs and equipment of vessels, methods of storage and displaying, and international certificates, etc. The following are six technical Annexes of the MARPOL73/78:

Annex I: Regulations for the Prevention of Pollution by Oil;26

Annex II: Regulations for the Control of Pollution by Noxious Liquid Substances in Bulk;27

Annex III: Regulations for the Prevention of Pollution by Harmful Substances Carried by Sea in Packaged Form; 28

Annex IV: Regulations for the Prevention of Pollution by Sewage from ships;29

Annex V: Regulations for the Prevention of Pollution by Garbage from Ships; 30 and

Annex VI: Regulations for the Prevention of Air Pollution from Ships. 31

\footnotetext{
24 This data of permissions issued by the Ministry of Environment is published at the homepage of the Ministry of Environment, available at http://www.env.go.jp/earth/kaiyo/ocean_disp/3hakkyu/index.html (last visited on Oct. 14, 2009).

25 While Annexes I and II are obligatory for Contracting Parties to accept, the other Annexes are optional. The MARPOL 73, art. 14, para. 1.

26 Entered into force in 1983.

27 Entered into force in 1983.

28 Entered into force in 1992.

29 Entered into force in 2003.

30 Entered into force in 1988.

31 Entered into force in 2005
} 
The ratio of the combined merchant fleets of the Contracting Parties to the gross tonnage of the world's merchant shipping at October 2, 2009 is $99.14 \%$ for Annexes I and II, 95.76\% for Annex III, 81.62\% for Annex IV, 97.18\% for Annex V, and 80.46\% for Annex VI.32 The international rules and standards set forth in the MARPOL 73/78, its Annexes and the Protocol of 1997 may be considered as de facto "generally accepted rules and standards." 33 In the meantime, Japan amended the Marine Pollution Prevention Act in 1983 and the related ministerial ordinances in order to ratify the MARPOL 73/78.

Japan passed the 2004 amendment of the Marine Pollution Prevention Act in order to prepare for entry into force of the Protocol of 1997 which prevents air pollution via nitrogen oxide ("NOx") emitting from engines of vessels. This amendment obliges ship owners to install and operate their engines compatible with such standards, as well as to use the fuel of vessels compatible with the standards on sulfur oxide.34 The 2004 amendment of the Act entered into effect on 19 May 2005, the same date the Protocol of 1997 entered into force.

\section{Japanese Enforcement of Laws and Regulations for Marine Environmental Protection and its Policy}

\section{A. Japanese Implementation of International Maritime Treaties in General}

There are only a limited number of grounds recognized by international law for States to exercise jurisdiction in order to regulate marine pollution. UNCLOS has largely codified the rules on jurisdiction, and recognizes three forms of national jurisdiction; that of the flag State, that of the coastal State, and that of the State of a port into which a vessel entered voluntarily. 35

UNCLOS authorizes coastal States to enforce their domestic laws and regulations against marine pollution from foreign vessels, not only in their internal waters and territorial sea, but also in their Exclusive Economic Zones ("EEZ"). ${ }^{36}$ And, under UNCLOS, port States are also entitled to undertake investigations and institute

\footnotetext{
32 These rations are published at "Summary of Status of Convention" of the IMO website, available at http://www.imo. org (last visited on Oct. 14, 2009).

33 UNCLOS, art. 211, para. 2.

34 Marine Pollution Prevention Act, art. 19(3 \& 21).

35 Supra Note 19, at 343-344.

36 UNCLOS, art. 220, paras. 5-6.
} 
proceedings regarding any discharge from foreign vessels in violation of "applicable international rules and standards" on the high seas, when the vessel is voluntarily within a port of the State. 37

If Japanese laws and regulations have been established in such a way as to amend existing laws or legislating new laws, etc. in order to implement international treaties, the Japanese Government may, at sea, apply and enforce its laws and regulations, prevent and suppress crimes, and detect and arrest criminals. For example, if each of the rights granted to Contracting Parties of UNCLOS is accepted by Japanese laws and regulations with penalties, the Japan Coast Guard may, in the event of violation of such laws and regulations, arrest, seize property, and bring or refer a suspect to the Public Prosecutors Office, etc., in accordance with the Code of Criminal Procedure. 38

Japan faces difficulties in implementing the rights and duties provided under UNCLOS, as it does not necessarily have sufficient domestic laws and regulations to implement such rights and duties. Some of those are directly or indirectly applied and enforced by the Japanese Government. For example, Japanese laws and regulations do not have provisions recognizing Japan's right of hot pursuit under international law, while some provisions presuppose that Japan has such rights. For example, there is a detailed provision as to the way to send a stop signal to a foreign vessel when exercising the right of hot pursuit against that vessel.

However, Article 31 of the Constitution of Japan stipulates as follows: "No person shall be deprived of life or liberty, nor shall any other criminal penalty be imposed, except according to procedure established by law." Under such a constitutional principle, prohibition and punishment against certain activities that Contracting Parties are permitted to regulate under UNCLOS may not be applied and enforced against any person under Japanese jurisdiction, without a legal provision stipulating any prohibition and punishment.

Accordingly, before Japanese government exercises criminal jurisdiction over activities at sea, Japanese laws and regulations stipulating prohibition and punishment in accordance with international law need to be established.

\section{B. Enforcement of the Marine Pollution Prevention Act}

The Japan Coast Guard Act ("JCG Act")39 is one of the most important set of laws and regulations for exercising jurisdiction at sea. Article 1 of the JCG Act provides the establishment and purpose of the Japan Coast Guard ("JCG"). Article 2 defines the

\footnotetext{
37 Id. at art. 218, para. 1.

38 Act No. 131 of 1948.

39 Act No. 28 of 1948.
} 
missions of the JCG in general, including the "prevention of marine pollution." Article 5 stipulates the twenty-nine definite missions that the JCG shall carry out, including "matters concerning prevention of marine pollution."

The JCG is authorized to exercise administrative enforcement jurisdiction on the basis of the "enforcement of laws and regulations at sea" under Article 2, Paragraph 1 of the JCG Act. Moreover, the JCG could exercise judicial enforcement jurisdiction on the basis of the "prevention and suppression of crimes at sea" and the "detection and arrest of criminals at sea." 40 Article 15 stipulates as follows: "When officers of the JCG are engaged in enforcing laws or regulations, they shall be deemed to be acting as agents of the particular administrative office charged with the administration of the particular law or regulations." This provision authorizes JCG officers to exercise general and comprehensive enforcement jurisdiction in order to manage all sorts of activities at sea.

Article 17 of the JCG Act provides three authorities for officers of the JCG as follows: (1) the authority to order the production of the official papers on the vessel; (2) the authority to stop, visit and inspect the vessel; and (3) the authority to question the crew and passengers of the vessel.

In order to prevent marine pollution, the JCG officers may inspect vessels in accordance with Article 17 of the JCG Act. Article 17 is an enforcement procedure to ascertain the compliance of marine environmental laws and regulations including the Marine Pollution Prevention Act. The officers may, in the event of violation of such laws and regulations, exercise criminal jurisdiction in accordance with the Code of Criminal Procedure.

UNCLOS has no provisions on the exercising of enforcement jurisdiction by coastal States in case of dumping or discharge from foreign vessels in local waters in violation of the coastal states' laws and regulations. It can be interpreted that coastal states, on the basis of their sovereignties or sovereign rights, may exercise such jurisdiction freely by applying domestic laws and regulations to those polluting activities in internal waters and deciding the legality of such acts. The Marine Pollution Prevention Act, however, addresses such illegal activities in internal waters by means of "the bond system." This system requires prompt release of vessels or crew arrested for such illegal activities upon the posting of a reasonable bond or other financial security.41 This system has been adopted as Japanese policy and in no way as implementation of an obligation under international treaties including UNCLOS.

In case of dumping or discharge from foreign vessels in the territorial sea the coastal State has the right to inspect foreign vessels. However, the coastal State shall exercise this right in the way that it does not hamper the innocent passage of its vessels.

40 Japan Coast Guard Act, art. 5(11).

41 UNCLOS, art. 292. 
UNCLOS stipulates that, in case a foreign vessel commits "any act of willful and serious pollution" 42 in the territorial sea, its coastal State may deny the innocence of passage, and take "the necessary steps" 43 which includes the exercise of enforcement jurisdiction. The Marine Pollution Prevention Act, however, addresses such pollution by means of the bond system, which is also adopted as Japanese policy. Even if a coastal state commences its judicial proceedings, it may only impose a pecuniary penalty, and its proceeding is suspended if the flag state of that vessel invokes similar judicial proceedings within six months.

Additionally, in case of dumping or discharge from a foreign vessel in an EEZ or on the high seas, Japan will inspect the vessel and investigate any polluting activities only after its voluntary entry into a Japanese port.44 Whereas UNCLOS allows port states to undertake investigation and institute proceedings in case of discharge from a foreign vessel in violation of "applicable international rules and standards" in EEZ,45 Japan will only seek information regarding the vessel, and notifies the vessel's flag state of such a discharge.

\section{Conclusion}

The Japanese practices of exercising jurisdiction over marine polluting activities by foreign vessels, such as giving careful consideration to the interests of navigation through the bond system, are interpreted to be in accordance with international law and to be based on the high considerations of the interests of comity with other States and the freedom of navigation. However, in order to take more effective measures against the protection and preservation of the marine environment, the time has come to reconsider Japan's "moderate exercise of jurisdiction." At the least, the exercising of the port states jurisdiction to marine polluting activities is a very attractive alternative. This option presents no danger to the freedom of navigation, and affords better facilities for investigation and the collection of evidence concerning polluting activities at the early stage, wherever such activities have taken place. 46

42 Id. at art. 19, para. 2(h).

43 Id. at art. 25, para. 1.

44 Id.

45 Id. at art. 218, para. 1.

46 The exercising of the port States' jurisdiction covers polluting activities both on the high seas outside an EEZ and within the coastal zones of another State, although in the latter case the port State may only act in response to a request from the State concerned. See Patricia BiRnie and Alan Boyle, International LaW \& the Environment 375 (2002). 
